\title{
ДОСВІД ВИКЛАДАННЯ АКУШЕРСТВА ТА ГІНЕКОЛОГІЇ В УМОВАХ КРЕДИТНО-МОДУЛЬНОЇ СИСТЕМИ
}

\author{
Л. В. Пахаренко, С. Л. Стефанко \\ ДВНЗ “Івано-Франківський національниймедичний університет”
}

\section{EXPERIENCE OF TEACHING OF OBSTETRICS AND GYNECOLOGY IN THE CONDITIONS OF CREDIT-MODULAR SYSTEM}

\author{
L. V. Pakharenko, S. L. Stefanko \\ SHEI "Ivano-Frankivsk National Medical University"
}

\begin{abstract}
У статті наведено досвід викладання акушерства та гінекології в умовах кредитно-модульної системи навчання. Викладено основні методики, що застосовуються в процесі навчання, наведено переваги та моменти, що потребують обговорення.
\end{abstract}

The article presents the experience of teaching of Obstetrics and Gynecology in the conditions of the credit-modular system. Main methods, which are used in the course of the study, advantages and points which need discussion are described.

Вступ. Реорганізація педагогічного процесу в умовах Болонської системи є непростим процесом, особливо для вищої медичної школи. Розвиток медицини, науки та сучасних технологій спонукає до змін і в системі медичної освіти, одним з основних завдань якої $є$ підготовка спеціалістів високого рівня. Модернізація системи освіти надасть можливість спеціалісту бути не тільки конкурентоспроможним в умовах ринку, але, що є основним, надати пацієнту кваліфіковані послуги в медичній галузі з урахуванням індивідуального підходу до кожної людини $[1,2]$.

Основна частина. На кафедрі акушерства та гінекології за кредитно-модульною системою навчаються студенти IV, V, VI курсів медичного факультету та факультету підготовки іноземних громадян. Програма $з$ дисципліни «Акушерство та гінекологія» структурована на 4 модулі. Модулі 1 та 2 передбачають вивчення фізіологічного та патологічного акушерства, модуль 3 - вивчення гінекології, модуль 4 акушерства та гінекології. Базова програма 3 акушерства та гінекології передбачає ознайомлення 3 деякими моментами з ендоскопічних технологій, однак не в повному обсязі. Зважаючи на недостатне висвітлення питання ендоскопічних втручань в базовій програмі, а також швидкий розвиток сучасних медичних технологій у вищі медичні навчальні заклади III-IV рівня акредитації було введено елективний курс «Ендоскопічні втручання в акушерстві та гінекології» для студентів V та VI курсів.
На кафедрі наявне до кожного практичного заняття методичне забезпечення (українською, російською та англійською мовами) у вигляді календарно-тематичних планів практичних занять, тематичного плану для самостійної роботи студентів, методичних розробок практичних занять для викладачів та студентів, пакета тестового контролю знань, набору ситуаційних занять та методичних вказівок для самостійної роботи студентів, тематичні таблиці та відеоматеріали.

Проведення педагогічного процесу в умовах Болонської системи має певні переваги. Зокрема, розроблена система оцінки як поточної навчальної діяльності студента у балах від «0» до «8» залежно від модуля, так і для оцінювання підсумкового модульного контролю. Кожен бал розподіляється на оцінку тестового контролю знань, теоретичної підготовки, самостійної роботи та ін. Аналогічно у балах оцінюється практична підготовка студента. Відмова від конвертації традиційної оцінки у бали дозволяє більш диференційовано оцінити знання та уміння 3 кожної теми $[3,4]$.

Відведено більше часу на самостійну роботу студента біля ліжка хворого. Даний вид роботи дозволяє формувати навики клінічного мислення, основаного на самостійному обстеженні хворого, встановленні попереднього діагнозу, визначення плану обстеження та лікування.

Інтеграція медичної освіти та науки в Свропейську систему навчання передбачає не тільки реорганізацію

(С Л. В. Пахаренко, С. Л. Стефанко 
педагогічного процесу, але й підготовку фахівців з інших країн. Програма єєдиною як для українських студентів, так і студентів-іноземців. Безперечним плюсом $\epsilon$ те, що викладачу, готуючись до проведення практичного заняття іноземною мовою, необхідно ознайомитись із сучасними закордонними науковими джерелами. Це стимулює викладача до удосконалення своєї професійної діяльності, поширення міжнародних контактів.

На кафедрі широко використовуються мультимедійні технології для читання лекцій як українським, так і іноземним студентам, наявний відеоматеріал (навчальні фільми, електронні підручники та посібники), що може бути використаний для проведення практичного заняття.

Однак, існують деякі суперечливі моменти, які вимагають подальшої дискусії. Скорочення годин лекційного матеріалу в умовах кредитно-модульної системи з однієї сторони позбавляє студентів цінного моменту педагогічного процесу, не дозволяє в повному обсязі викласти лектору всі положення теми, особливо в тих випадках, коли є об'єднання двох тем. Проте, це спонукає студента до самостійної роботи.

На нашу думку, написання навчальної історії хвороби у першому модулі «Фізіологічний перебіг вагітності, пологів та післяпологового періоду» є недоцільним. Згідно з програмою студент має самостійно під наглядом викладача провести обстеження вагітної, роділлі та породіллі, взяти участь у пологах, вести роботу з медичною документацією. Програма першого модуля не передбачає вивчення значної кількості патологічних станів в акушерстві, а на сьогодні, враховуючи сучасні принципи акушерської служби, на госпіталізації знаходяться вагітні жінки із певними патологічними станами. Приблизно 60-80\% вагітних жінок мали обтяжений акушерський анамнез. Тому, вважаємо, що написання та захист навчальної історії слід перенести у другий модуль, коли студент ознайомився iз значною кількістю акушерської патології і зможе більш осмислено оцінити даний вид роботи.

Позитивним моментом є і те, що програма передбачає надання консультацій студентам для підготовки до практичного заняття. Проте, лише деякі студенти виявляють необхідність у даному виді роботи. Часто консультації для студентів залишаються поза їхньою увагою, що свідчить про відсутність мотивації до самостійного навчання. Також є відкритим питання забезпечення студентів всіма необхідними матеріалами для відпрацювання практичних навичок (сучасними фантомами, муляжами, тренінговим устаткуванням та ін.), що є вкрай недостатнім.

Відомо, що іноземні студенти володіють значно нижчим рівнем підготовки, в тому числі із базових предметів, тому $\epsilon$ необхідність витрачати час на практичному заняті на повторення базових знань 3 таких предметів, як анатомія, нормальна фізіологія та ін. Проблемним питанням $є$ самостійна робота студентів «біля ліжка хворого», оскільки деякі студенти не володіють достатнім рівнем української чи російської мови для проведення бесіди із пацієнтом. Тому виникає необхідність у залученні до практичних занять стандартизованих пацієнтів.

Висновок. В умовах кредитно-модульної системи навчання організація педагогічного процесу вимагає різностороннього підходу до проведення практичного заняття. Вона має суттєві переваги, однак, на нашу думку, на початковому етапі ії впровадження слід дотримуватись компромісу між новітніми технологіями навчання та так званим традиційним підходом.

контексті вимог Болонської декларації / I. Є. Булах, О. П. Волосовець, М. Р. Мруга // Медична освіта. - 2011. № 2. - С. 20-22.

4. Медведенко Н. В. Модульно-рейтинговая технология оценки достижений студентов вуза/Н.В.Медведенко // Стандарты и мониторинг в образовании. - 2008. - № 1.-С. 18-22. 